\title{
Establishment of Reciprocal Micrografting of Tomato (Solanum lycopersicum L.) and Eggplant (Solanum melongena L.)
}

\author{
Dinh Truong Son ${ }^{1}$ and Tran Thi Tham ${ }^{2}$ \\ ${ }^{1}$ Department of Plant Biotechnology, Faculty of Biotechnology, Vietnam National \\ University of Agriculture, Hanoi 131000, Vietnam \\ ${ }^{2}$ Vietnam Likado Joint Stock Company, Hanoi 127000, Vietnam
}

\begin{abstract}
Micrografting can be used as a key tool to investigate genefunction, long-distance signal transduction, or metabolite movement in different developmental and physiological stages. In plant production, plant grafting can be applied to improve productivity and/or increase the tolerance of plants to stresses. Here, we describe a simple and high efficiency protocol for reciprocal micrografting of tomato (Solanum lycopersicum L.) and eggplant (Solanum melongena L.). Tomato and eggplant seeds can be disinfected with $0.5 \%$ Presept for $20 \mathrm{~min}$ before germinating on MS media. Seedlings of 5-day-old tomatoes and 15-day-old eggplants were suitable for preparation of scions and rootstocks. Scions were cut into $0.5-1 \mathrm{~cm}$ lengths for micrografting. Sucrose levels greatly influenced the graft success rate of all graft combinations including of self- and reciprocal micrografting between tomato and eggplant. While self-grafted tomatoes or eggplants required $20 \mathrm{~g} \mathrm{~L}^{-1}$ sucrose to get the highest grafting success rate ( $72 \%$ for tomato and $100 \%$ for eggplant), reciprocal micrografting of tomato/eggplant and eggplant/tomato reached the highest success rate $(83 \%)$ on MS medium supplemented with $30 \mathrm{~g} \mathrm{~L}^{-1}$ sucrose. Grafted plants should be cultured under the illumination conditions of a $16 \mathrm{~h}$ light/ $8 \mathrm{~h}$ dark cycle for optimal growth and quality.
\end{abstract}

\section{Keyword}

Micrografting, grafting, tomato (Solanum lycopersicum L.), eggplant (Solanum melongena L.)

\section{Introduction}

Grafting is a horticultural technique that is used to join parts

Correspondence to dtson@vnua.edu.vn

ORCID

Son Truong Dinh https://orcid.org/0000-0002-55380173 from two or more plants so that they appear to grow as a single plant. The grafting technique has been widely used for vegetative propagation to improve productivity (Gulati et al., 2001; Grigoriadis et al., 2005; Melnyk and Meyerowitz, 2015; Rehman and Gill, 2015; Gaion et al., 2018), as avalid alternative to traditional 
micropropagation in the case of Pelecyphora aselliformis Ehrenberg (Badalamenti et al., 2016), or to increase the tolerance of plants to stresses such as the interspecific grafting of eggplant onto tomato for verticillium wilt resistance (Miles et al., 2015). Moreover, grafting can be used to investigate long-distance signaling in Arabidopsis, and systemic signaling in Nicotiana attenuata in response to herbivory (Turnbull et al., 2002; Li et al., 2016; Regnault et al., 2016; Bozorov et al., 2017; Tsutsui and Notaguchi, 2017). In Vietnam, the protocol for grafting tomato onto eggplant has also been established and applied in practical production (Ha, 2009).

The success of plant grafting largely depends on the connection and formation of vascular tissues at the graft junction. Since the cambium connection between the scion and rootstock will later give rise to phloem and xylem during secondary growth, using similar sized scions and rootstocks are required (Melnyk and Meyerowitz, 2015).

In the in vivo grafting technique, the union of the xylem at the graft junction strongly influences the movement of water and nutrients in the xylem and phloem of the vascular system, thereby affecting the growth potential of the grafted plant (Atkinson et al., 2003). In addition, it has been shown that a phloem graft union is a main reason of long-term incompatibility; therefore, plant grafting methods that do not affect plant development should be developed (Goldschmidt, 2014).

In Nicotiana attenuata, micrografting plants do not show growth reductions compared to non-grafted plants. Moreover, micrografting $N$. attenuata can be used as a key tool to evaluate gene function, and long-distance signal transduction in different developmental and physiological processes (Fragoso et al., 2011).

Although micrografting efficiency in some plants is high, the success rate largely depends on species (Fragoso et al., 2011). Here, we describe a simple and highly efficient micrografting method for reciprocal micrografting of tomato (Solanum lycopersicum L.) and eggplant (Solanum melongena L.).

\section{Materials and Methods}

\section{Materials}

Seeds of tomatoes, VNS 585 (F1 hybrid variety), were imported from India and supplied by the Southern Seed Corporation. Seeds of eggplant, PD612 variety, were provided by Phu Dien Trading and Production Company Limited, Hanoi, Vietnam.

\section{Methods}

\section{Plant cell culture method}

Murashige and Skoog (1962) (MS) culture medium was used to culture the plant cells and was supplemented with $8 \mathrm{~g} \mathrm{~L}^{-1}$ agar and $30 \mathrm{~g} \mathrm{~L}^{-1}$ sucrose (unless otherwise indicated). The $\mathrm{pH}$ was adjusted to 5.7-5.8 before being autoclaved. All the experiments followed a completely randomized design with three replications.

\section{Sterilization method}

Seeds were washed under running water, rinsed with $70 \%$ ethanol for 30 seconds, and then treated with either $0.1 \% \mathrm{HgCl}_{2}$ or $0.5 \%$ Presept solution (Product of Johnson \& Johnson, containing sodium dichloroiso cyanurate) supplied with 1-2 drops of Tween 20 , and treated with different exposure times. During the sterilization process, the containers were shaken vigorously. Seeds were then rinsed in sterile water five times. Sterilized seeds were placed on MS basal medium for germination. For establishment of the sterilization regime, 100 seeds were used for each treatment.

\section{Micrografting methods}

Seedlings were cut horizontally across the hypocotyl to prepare the scions or rootstocks. Rootstocks and scions were then placed in contact with each other. A nylon tube was used to wrap each scion and rootstock at the graft junction to keep the scion and rootstock stable. Grafted plants were then placed horizontally on the surface of the MS basal medium and kept in a culture room. Twenty-five grafted plants (selfor reciprocal grafted) were used for each treatment.

To evaluate the illumination conditions, two light regimes were used: dark conditions (for the first five days, the grafted plants were kept in darkness, and then after that they were exposed 
to the normal light regime) and normal light conditions (16 h light/8 h dark).

Samples were kept in plant growth room under a light intensity of 2000 lux, 70\% humidity, $24 \pm 2^{\circ} \mathrm{C}$, and photoperiodic lighting of $16 \mathrm{~h} \mathrm{light} / 8 \mathrm{~h}$ dark cycles, unless otherwise indicated.

Statistical Analyses: All data were analyzed by Excel version 2013. Data shown in Tables 2, 3,4 and 5 , means are presented as averages \pm standard errors (SE).

\section{Results and Discussion}

\section{Effects of the sterilization regime on the establishment of aseptic seedlings}

Selecting clean explants is the most important factor for being successful at the initial culture stage of plant tissue culturing. Since the uniformity of samples will greatly affect the interpretation of results, we decided to use seeds of tomato and eggplant instead of shoots or other materials as initial explants. Moreover, seed sterilization is often easier and seeds are considered free from some diseases such as bacteria or even some viruses. Since $0.1 \% \mathrm{HgCl}_{2}$ has been used to sterilize tomato seeds for 5 min (Zhang et al., 2012), and sodium dichloroisocyanurate (active component of Presept) is known to be less toxic to explants and therefore can be used at a wide range of concentrations $(0.5-2.0 \%)$ for different periods of time (from 5-90 min) (Mihaljević et al., 2013; Kendon et al., 2017), we decided to use both $0.1 \% \mathrm{HgCl}_{2}$ and $0.5 \%$ Presept for sterilization.

The results shown in Table 1 indicated that although seeds were treated differently with two sterilizing agents $\left(\mathrm{HgCl}_{2}\right.$ or Presept solution) at different durations, all four treatments produced $100 \%$ sterilized seeds. These results demonstrated that the tomato and eggplant seeds were of good quality which led to the high efficiency of the sterilizing agents. More importantly, $100 \%$ of the tomato seeds and at least $92.5 \%$ of the eggplant seeds germinated and all the seedlings grew very well. These results suggest that the tomato and eggplant seeds were slightly or not affected by the disinfectants. Therefore, both $\mathrm{HgCl}_{2}$ and a Presept solution can be used to disinfect tomato and eggplant seeds. However, since $\mathrm{HgCl}_{2}$ is toxic to humans as well as the environment, it is therefore highly recommended to use a $0.5 \%$ Presept solution to disinfect tomato and eggplant seeds.

Effects of plant age after germination on the success rate of self-grafted tomato and eggplant

There are many factors (grafting procedure, grafting position, scion types, and scion length, etc.) that affect the success rate of grafting and plant age is one factor of great importance (Mneney and Mantell, 2001; Khalafalla and Daffalla, 2008; Tanuja et al., 2017). To overcome the incompatibility situation in interspecific micrografting, we decided to work on self-grafted tomatoes or eggplants only. Based on their growth rates, we used tomato plants at the ages of 5, 10, and 15 days after germination, and eggplant plants at the ages of 9,12 , and 15 days after germination.

The age of the tomato plants strongly affected the success rate of the micrograft, and in general, the older plants were, the lower grafting success rate was (Table 2). The highest

Table 1. Effects of the sterilization regime on the establishment of an aseptic seedlings 10 days after sterilization

\begin{tabular}{|c|c|c|c|c|c|}
\hline \multirow{2}{*}{$\begin{array}{l}\text { Sterilizing agent } \\
\text { solution }\end{array}$} & \multirow{2}{*}{$\begin{array}{l}\text { Duration } \\
\text { (min) }\end{array}$} & \multicolumn{2}{|c|}{ Tomato seeds } & \multicolumn{2}{|c|}{ Eggplant seeds } \\
\hline & & $\begin{array}{c}\text { Sterilized seeds } \\
(\%)\end{array}$ & $\begin{array}{c}\text { Germination rate } \\
(\%)\end{array}$ & $\begin{array}{l}\text { Sterilized seeds } \\
(\%)\end{array}$ & $\begin{array}{c}\text { Germination rate } \\
(\%)\end{array}$ \\
\hline $0.1 \% \mathrm{HgCl}_{2}$ & 5 & 100 & 100 & 100 & 100 \\
\hline $0.1 \% \mathrm{HgCl}_{2}$ & 10 & 100 & 100 & 100 & 100 \\
\hline 0.5\% Presept & 20 & 100 & 100 & 100 & 92.5 \\
\hline 0.5\% Presept & 30 & 100 & 100 & 100 & 95.0 \\
\hline
\end{tabular}


Table 2. Effects of plant age on the success rate of self-grafted tomato and self-graft eggplant two weeks after grafting

\begin{tabular}{|c|c|c|c|c|c|c|}
\hline & $\begin{array}{l}\text { Days after } \\
\text { germination } \\
\text { (days) }\end{array}$ & $\begin{array}{l}\text { Percentage of } \\
\text { successful grafts } \\
(\%)\end{array}$ & $\begin{array}{l}\text { Number of leaves } \\
\text { (leaves/plant) }\end{array}$ & $\begin{array}{l}\text { Number of roots } \\
\text { (roots/plant) }\end{array}$ & Stalk length $(\mathrm{cm})$ & $\begin{array}{l}\text { Growth } \\
\text { observation }\end{array}$ \\
\hline \multirow{3}{*}{ 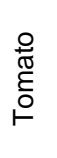 } & 5 & 53.8 & $2.1 \pm 0.14$ & $1.1 \pm 0.14$ & $4.5 \pm 0.19$ & Very good \\
\hline & 10 & 25.0 & $2.6 \pm 0.40$ & $1.6 \pm 0.24$ & $4.9 \pm 0.40$ & Good \\
\hline & 15 & 15.0 & $2.7 \pm 0.33$ & $1.7 \pm 0.33$ & $5.7 \pm 0.33$ & Good \\
\hline \multirow{3}{*}{ 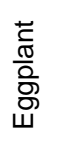 } & 9 & 60.0 & $2.8 \pm 0.14$ & $1.1 \pm 0.08$ & $3.3 \pm 0.12$ & Very good \\
\hline & 12 & 60.0 & $3.6 \pm 0.15$ & $2.0 \pm 0.25$ & $3.8 \pm 0.18$ & Very good \\
\hline & 15 & 68.0 & $3.8 \pm 0.12$ & $2.0 \pm 0.23$ & $4.1 \pm 0.22$ & Very good \\
\hline
\end{tabular}

grafting success rate (53.8\%) was achieved when the tomato plants were grafted at the age of 5 days after germination, followed by 10 days after germination (25.0\%), and the lowest grafting success rate was only $15.0 \%$ when the age of plants was 15 days after germination. The highest success rate of the 5-day-old plants could be explained in that these plants were still at an early stage after germination, so they were younger and therefore better facilitated to the rejoining process at the graft junction. In fact, in in vivo sweet pepper (Capsicum annuиm L.) grafting, the plant age has been shown to influence the results of grafting and older plants had a lower percentage of xylem connections than younger plants (Johkan et al., 2009). Therefore, younger plants showed higher grafting success rates than older plants.

We also collected the growth data of the grafted tomato seedlings in order to evaluate the effects of plant age on their success rate. The plants grafted 5 days after sowing showed the shortest stalk and root lengths, and the lowest leaf number; however, it was obvious that the total growth time (days after sowing) of plants grafted at the ages of 10 and 15 days were 5 or 10 days more than that of the plants grafted 5 days after sowing, respectively (Figure 1). Therefore, it could be concluded that tomato plants at 5 days after sowing are the most suitable for micrografting.

The age of the eggplant plants showed the opposite effect when compared with the results collected from the tomato plants. While the younger tomato plants had higher success rates, the older eggplant plants showed higher success rates than the younger ones. The highest grafting success rate $(68 \%)$ was achieved when eggplant plants 15 days after sowing were used.

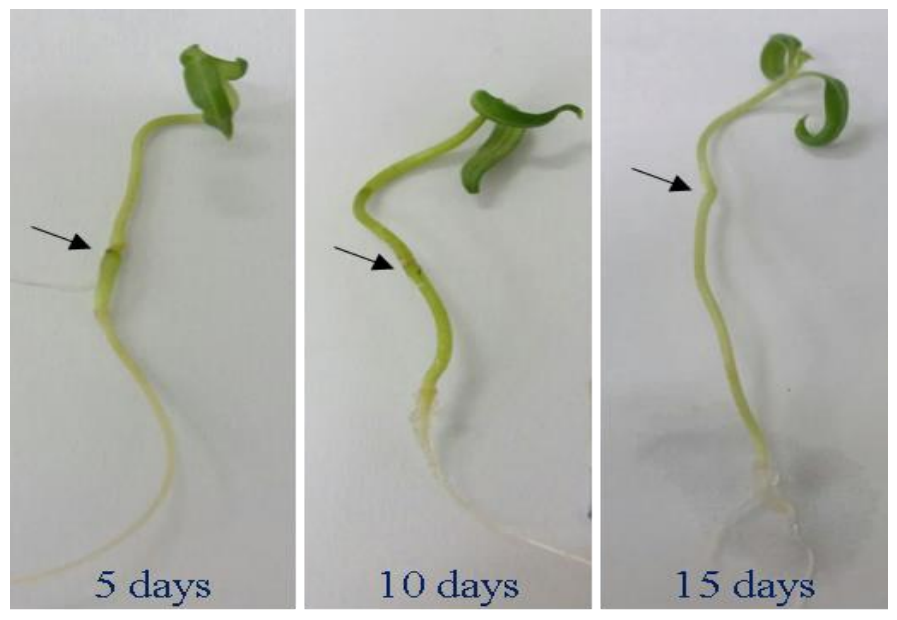

Note: The dark arrow indicates the graft junction.

Figure 1. Effects of plant age on the success rate of self-grafted tomato two weeks after grafting 
The 9 or 12-day-old plants showed the same success rate of $60 \%$ after two weeks. These results are in agreement with the micrografting results of Acacia senegal (L.) Wild in which 14day-old rootstocks had higher success rates than 7-day-old rootstocks (Khalafalla and Daffalla, 2008).

It should be noted that two weeks after grafting, the stalk lengths of the tomato plants reached 4.5-5.7 cm; however, the stalk lengths of the eggplants reached only 3.3-4.1 cm after the same culturing time. Moreover, before grafting, eggplants exhibited smaller sizes than tomatoes (data not shown). These results indicated that eggplant plants grew relatively slower than tomato plants which could be one of the reasons why eggplant plants required a longer time after sowing to reach the right stage for grafting. Nevertheless, $68 \%$ of the grafts were successful and the grafted plants grew well, therefore, 15 days after sowing is the right stage for eggplant plants to be used for micrografting.

\section{Effects of scion size on the success rate of reciprocal micrografting}

From the previous experiments, we have known that plant age is one of the factors affecting the success of grafting (Table 2, Figure 1). It has also been reported that the rate of successfully grafted plants is influenced by scion size (Khalafalla and Daffalla, 2008). Therefore, we conducted an experiment to evaluate scion size on grafting. To overcome the incompatibility between scions and rootstocks, we worked only on self-grafted tomatoes or eggplants. Data are presented in Table 3.

In general, different sizes of scions ( 0.5 and $1.0 \mathrm{~cm}$ ) did not affect the grafting success rate.
Self-grafted tomatoes that had scion sizes of 0.5 $\mathrm{cm}$ or $1.0 \mathrm{~cm}$ had success rates of $63 \%$ and $65 \%$, leaf numbers of 2.7 and 3.1, and root numbers of 1.0 and 1.1 per plant, respectively. In addition, stalk length did not dramatically change $(5.5$ vs $4.6 \mathrm{~cm})$. Self-grafted eggplants showed the same trends in success rates, leaf numbers, and root numbers with the self-grafted tomatoes. In grafting, scion size has been known to affect the success rate of Acacia senegal (L.) Wild (Khalafalla and Daffalla, 2008). In in vivo mango grafting, the size and age of scions do not affect the grafting success in the spring season; however, from July to September, bigger scions result in higher success rates (Majhail and Singh, 1962). It could be that tomato and eggplant plants are more suitable for micrografting. In addition, in vitro plants exhibit higher success rates compared to scions collected from field (Sanjaya et al., 2006). Based on our results, it can be concluded that scion sizes of $0.5-1.0 \mathrm{~cm}$ are suitable for micrografting.

Effects of sucrose concentration on the success rate of reciprocal micrografting of tomato and eggplant

Sugar positively affects plant growth under in vitro conditions. In plant tissue culture, sucrose is the sugar most commonly supplied in media at a concentration of 20-30 $\mathrm{g} \mathrm{L}^{-1}$ (Khan et al., 2002; Sanjaya et al., 2006). The following experiment was conducted to evaluate the role of sucrose on reciprocal micrografting of tomato and eggplant.

The results in Figure 2 showed that sucrose levels had a great influence on the grafting success rate of all graft combinations between tomato and eggplant.

Table 3. Effects of scion size on the success rate of reciprocal micrografting two weeks after grafting

\begin{tabular}{|c|c|c|c|c|c|c|}
\hline Scion/rootstock & $\begin{array}{l}\text { Scion size } \\
\quad(\mathrm{cm})\end{array}$ & $\begin{array}{c}\text { Grafting } \\
\text { success rate } \\
(\%)\end{array}$ & $\begin{array}{c}\text { Number of } \\
\text { leaves } \\
\text { (leaves/plant) }\end{array}$ & $\begin{array}{l}\text { Number of roots } \\
\text { (roots/plant) }\end{array}$ & $\begin{array}{l}\text { Stalk length } \\
(\mathrm{cm})\end{array}$ & $\begin{array}{c}\text { Growth } \\
\text { observation }\end{array}$ \\
\hline \multirow[t]{2}{*}{ Self-grafted tomato } & 0.5 & 63 & $2.7 \pm 0.13$ & $1.0 \pm 0.0$ & $5.5 \pm 0.20$ & Very good \\
\hline & 1.0 & 65 & $3.1 \pm 0.21$ & $1.1 \pm 0.09$ & $4.6 \pm 0.20$ & Very good \\
\hline \multirow[t]{2}{*}{ Self-grafted eggplant } & 0.5 & 75 & $2.7 \pm 0.33$ & $1.0 \pm 0.0$ & $3.7 \pm 0.33$ & Good \\
\hline & 1.0 & 67 & $2.5 \pm 0.29$ & $1.0 \pm 0.0$ & $4.7 \pm 0.25$ & Very good \\
\hline
\end{tabular}

Note: Scion size was the length from shoot tip to the cut hypocotyl tissue. 


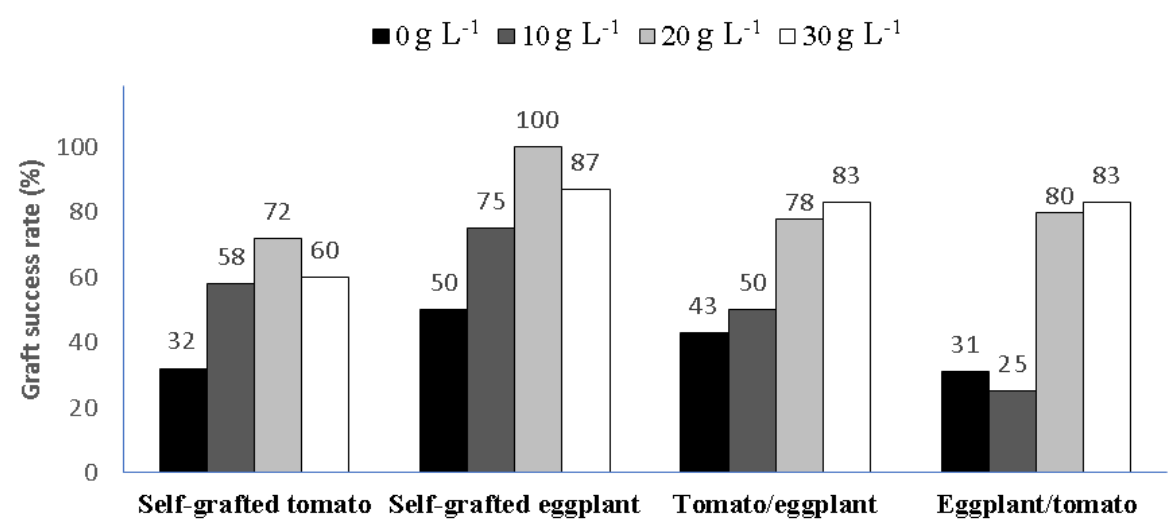

Figure 2. Effects of sucrose concentration on success rate of reciprocal micrografting two weeks after grafting

Self-grafted tomato plants reached the highest $(72 \%)$ success rate on MS medium supplemented with $20 \mathrm{~g} \mathrm{~L}^{-1}$ sucrose and the lowest $(32 \%)$ in the absence of sucrose. As in the self-grafted tomato plants, self-grafted eggplant also required $20 \mathrm{~g} \mathrm{~L}^{-1}$ sucrose in the medium to get the highest grafting success rate $(100 \%)$.

Interestingly, while the addition of $30 \mathrm{~g} \mathrm{~L}^{-1}$ sucrose in the self-grafted tomatoes and eggplants caused a reduction in the grafting success rate compared to the medium supplemented with $20 \mathrm{~g} \mathrm{~L}^{-1}$, the addition of $30 \mathrm{~g}$ $\mathrm{L}^{-1}$ sucrose increased the grafting success rate in micrografting (tomato/eggplant and eggplant/tomato) compared to the medium supplemented with $20 \mathrm{~g} \mathrm{~L}^{-1}$. Tomato/eggplant and eggplant/tomato grafted plants reached the highest success rate $(83 \%)$ on the medium supplemented with $30 \mathrm{~g} \mathrm{~L}^{-1}$ sucrose, followed by the $20 \mathrm{~g} \mathrm{~L}^{-1}$ sucrose treatments (78 and $80 \%$, respectively). Moreover, low levels of sucrose (without or with the addition of $10 \mathrm{~g} \mathrm{~L}^{-1}$ sucrose) affected the tomato/eggplant success

Table 4. Effects of sucrose concentration on the success rate of reciprocal micrografting two weeks after grafting

\begin{tabular}{|c|c|c|c|c|}
\hline Scion/rootstock grafting & $\begin{array}{l}\text { Sucrose } \\
\left(g^{-1}\right)\end{array}$ & $\begin{array}{l}\text { Number of leaves } \\
\text { (leaves/plant) }\end{array}$ & $\begin{array}{l}\text { Number of roots } \\
\text { (roots/plant) }\end{array}$ & $\begin{array}{c}\text { Growth } \\
\text { observation }\end{array}$ \\
\hline \multirow[t]{4}{*}{ Self-grafted tomato } & 0 & $2.2 \pm 0.16$ & $1.1 \pm 0.13$ & Good \\
\hline & 10 & $3.3 \pm 0.29$ & $1.7 \pm 0.18$ & Good \\
\hline & 20 & $3.5 \pm 0.27$ & $2.8 \pm 0.31$ & Very good \\
\hline & 30 & $3.3 \pm 0.33$ & $4.0 \pm 0.37$ & Very good \\
\hline \multirow[t]{4}{*}{ Self-grafted eggplant } & 0 & $2.3 \pm 0.33$ & $1.0 \pm 0.00$ & Good \\
\hline & 10 & $2.0 \pm 0.00$ & $1.3 \pm 0.33$ & Good \\
\hline & 20 & $2.8 \pm 0.40$ & $2.0 \pm 0.37$ & Very good \\
\hline & 30 & $3.6 \pm 0.30$ & $5.6 \pm 0.61$ & Very good \\
\hline \multirow[t]{4}{*}{ Tomato/eggplant } & 0 & $2.7 \pm 0.33$ & $1.0 \pm 0.00$ & Good \\
\hline & 10 & $2.0 \pm 0.00$ & $1.5 \pm 0.50$ & Good \\
\hline & 20 & $3.1 \pm 0.26$ & $2.1 \pm 0.26$ & Very good \\
\hline & 30 & $3.0 \pm 0.45$ & $2.0 \pm 0.49$ & Very good \\
\hline \multirow[t]{4}{*}{ Eggplant/tomato } & 0 & $3.6 \pm 0.24$ & $1.2 \pm 0.20$ & Good \\
\hline & 10 & $3.0 \pm 0.00$ & $1.0 \pm 0.00$ & Good \\
\hline & 20 & $4.0 \pm 0.41$ & $3.3 \pm 0.63$ & Very good \\
\hline & 30 & $3.2 \pm 0.20$ & $2.6 \pm 0.40$ & Very good \\
\hline
\end{tabular}




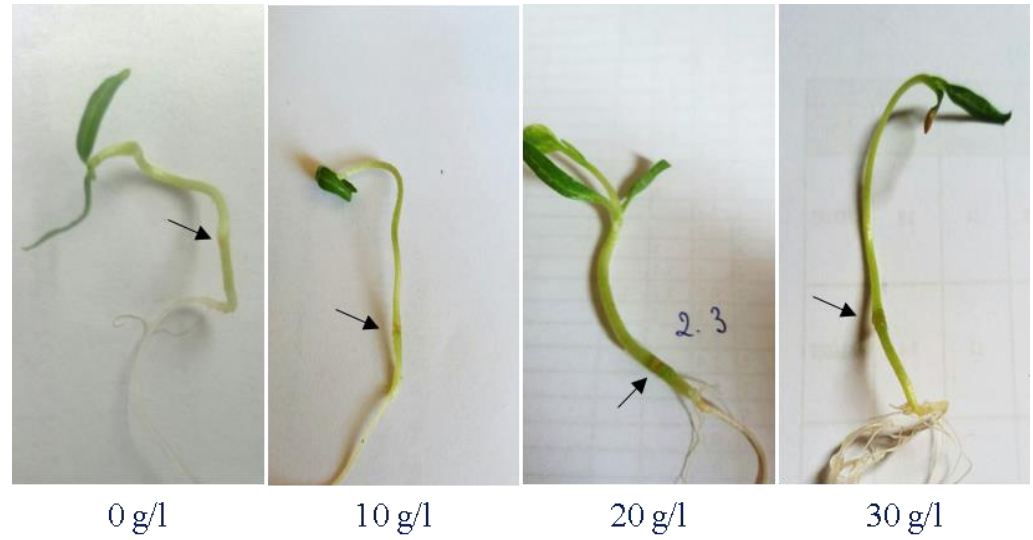

Note: The dark arrow indicates the graft junction.

Figure 3. Effects of sucrose concentration on success rate of eggplant/tomato micrografting two weeks after grafting

rate slightly, however, they dramatically reduced the success rate of eggplant/tomato grafting when compared to the self-grafted plants.

In addition to the grafting success rate, we evaluated the growth of the grafted plants. The results are presented in Table 4 and Figure 3. While, the levels of sucrose slightly affected leaf numbers on all the graft combinations, they dramatically influenced the root number, stalk length, and growth of the grafted plants. In general, MS media supplemented with 20-30 g $\mathrm{L}^{-1}$ sucrose resulted in excellent in growth of the grafted plants (self- and interspecific grafts). For example, the self-grafted tomato plants on the MS medium supplemented with $30 \mathrm{~g} \mathrm{~L}^{-1}$ sucrose resulted in an average of 3.3 leaves, 4.0 roots, and stalk lengths of $6.1 \mathrm{~cm}$, and the growth was very good. While on the MS medium without sucrose, the grafted plants only reached 2.2 leaves, 1.1 roots, and stalk lengths of $4.5 \mathrm{~cm}$. The growth trends were the same for all the other graft combinations as well.

Our data were in agreement with other reports which concluded that sucrose is important for the success of micrografting. In citrus micrografting, an increase of sucrose from 3.0 to $7.0 \%$ resulted in an increase in the grafting success rate (Naz et al., 2007). In addition, grapefruit micrografting also improved significantly when cultures were grown on MS medium supplemented with $7.5 \%$ sucrose compared to $3.0 \%$ (Hamaraie et al., 2005).

\section{Effects of illumination conditions on the success rate of reciprocal micrografting}

Illumination conditions such as continuous light, continuous dark, or a light dark cycle greatly influence in vitro culture results. In general, during in vitro culture, a light dark cycle is normally applied. In tomato, exposure to light increases the callus induction efficiency (RzepkaPlevneö et al., 2006); however, callus induction frequency in Bixa oreliana L. is higher in the dark (Khan et al., 2002). In grafting, forming calli at the junction is necessary for the union of the rootstock and scion since calli will later differentiate into phloem and xylem (Melnyk, 2017); therefore, an experiment was conducted to evaluate illumination conditions on the grafting success rate.

Light exposure increased the success rate of all the micrografting combinations, either selfor reciprocal grafting between tomato and eggplant (Figure 4). While culturing under continuous dark conditions gave grafting success rates between $30-50 \%$, exposure to a light regime of $16 \mathrm{~h} /$ day resulted in $52-86 \%$ graft success rates. Under the light exposure conditions, the self-grafted eggplants had the highest success rate (86\%), followed by tomato/eggplant (82\%). Interestingly, selfgrafted tomatoes had a success rate of only $52 \%$ while the reciprocal grafted combinations between eggplant and tomato were $70-82 \%$. These data indicate that eggplant has a higher tissue reunion efficiency than tomato, and thus, 


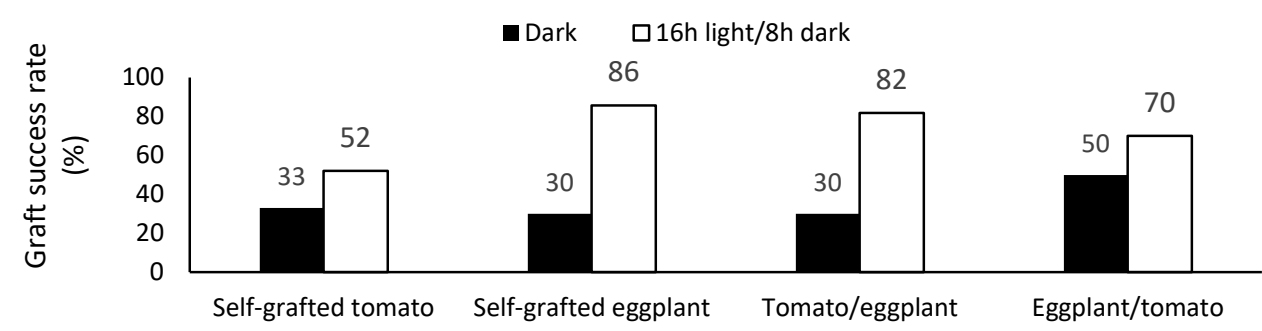

Figure 4. Effects of illumination conditions on success rate of reciprocal micrografting two weeks after grafting

Table 5. Effects of illumination conditions on the success rate of reciprocal micrografting two weeks after grafting

\begin{tabular}{llcccc}
\hline $\begin{array}{c}\text { Scion/rootstock } \\
\text { grafting }\end{array}$ & Illumination conditions & $\begin{array}{c}\text { Leaf number } \\
\text { (leaves/plant) }\end{array}$ & $\begin{array}{c}\text { Root number } \\
\text { (roots/plant) }\end{array}$ & $\begin{array}{c}\text { Stalk length } \\
\text { (cm) }\end{array}$ & $\begin{array}{c}\text { Growth } \\
\text { observation }\end{array}$ \\
\hline Self-grafted tomato & Dark & $2.0 \pm 0.00$ & $1.0 \pm 0.00$ & $5.7 \pm 0.25$ & Good \\
& $16 \mathrm{~h} \mathrm{light/8} \mathrm{h}$ dark & $2.2 \pm 0.12$ & $1.3 \pm 0.13$ & $4.8 \pm 0.13$ & Very good \\
$\begin{array}{l}\text { Self-grafted } \\
\text { eggplant }\end{array}$ & Dark & $2.7 \pm 0.33$ & $1.0 \pm 0.00$ & $3.3 \pm 0.33$ & Poor \\
& $16 \mathrm{~h} \mathrm{light/8} \mathrm{h}$ dark & $3.4 \pm 0.15$ & $1.1 \pm 0.08$ & $4.4 \pm 0.19$ & Very good \\
Tomato/eggplant & Dark & $2.3 \pm 0.33$ & $1.0 \pm 0.00$ & $4.7 \pm 0.33$ & Poor \\
& $16 \mathrm{~h} \mathrm{light/8} \mathrm{h}$ dark & $2.2 \pm 0.15$ & $1.1 \pm 0.11$ & $5.0 \pm 0.22$ & Very good \\
Eggplant/tomato & Dark & $3.0 \pm 0.00$ & $1.0 \pm 0.00$ & $4.5 \pm 0.50$ & Poor \\
& $16 \mathrm{~h} \mathrm{light/8} \mathrm{h}$ dark & $2.4 \pm 0.20$ & $1.4 \pm 0.20$ & $4.1 \pm 0.14$ & Very good \\
\hline
\end{tabular}

positively affected the grafting success rate. Indeed, self-grafted eggplant always showed the highest success rate (even 100\%) among all the graft combination (Figures 2 and 4). In addition to the grafting success rate, we also observed the growth of the grafted plants, and the results are presented in Table 5.

Although leaf number, root number, and stalk length were the same when the grafted plants grew under either dark or light conditions, based on morphology observations, exposure to the light dark regime of $16 \mathrm{~h}$ light $/ 8$ $\mathrm{h}$ dark resulted in a better quality of grafted plants when compared to the continuous dark conditions. All combinations of the grafted plants (self- or reciprocal grafted plant) performed well under the light regime of $16 \mathrm{~h}$ light/day while most of the plants grew poorly under the dark conditions. The results from this study were in agreement with previous studies which found improved grafting success and growth of grafted tomatoes under light compared to dark (Vu et al., 2014).

\section{Conclusions}

A simple and high efficiency protocol for the reciprocal micrografting of tomato (Solanum lycopersicum L.) and eggplant (Solanum melongena L.) was established. Tomato and eggplant seeds can be disinfected with $0.5 \%$ Presept for $20 \mathrm{~min}$ before germinating on MS media. Seedlings of 5-day-old tomatoes and 15day-old eggplants were suitable for preparation of scions and rootstocks. Scions cut into 0.5-1.0 $\mathrm{cm}$ lengths were suitable for micrografting. Self-grafted tomatoes or eggplants required $20 \mathrm{~g}$ $\mathrm{L}^{-1}$ sucrose to get the highest grafting success rates ( $72 \%$ for tomato and $100 \%$ for eggplant), however, reciprocal micrografting of tomato/eggplant and eggplant/tomato reached highest success rate $(83 \%)$ on MS medium supplemented with $30 \mathrm{~g} \mathrm{~L}^{-1}$ sucrose. Grafted plants should be cultured under a $16 \mathrm{~h}$ light $/ 8 \mathrm{~h}$ dark cycle for optimal growth and quality. 


\section{References}

Atkinson C. J., Else M. A., Taylor L. and Dover C. J. (2003). Root and stem hydraulic conductivity as determinants of growth potential in grafted trees of apple (Malus pumila Mill.). Journal of Experimental Botany. Vol 54. pp. 1221-1229.

Badalamenti O., Carra A., Oddo E., Carimi F. and Sajeva M. (2016). Is in vitro micrografting a possible valid alternative to traditional micropropagation in Cactaceae? Pelecyphora aselliformis as a case study. SpringerPlus. Vol 5. pp. 201.

Bozorov T. A., Dinh S. T. and Baldwin I. T. (2017). JA but not JA-Ile is the cell-nonautonomous signal activating JA mediated systemic defenses to herbivory in Nicotiana attenuata. Journal of Integrative Plant Biology. Vol 59. pp. 552-571.

Fragoso V., Goddard H., Baldwin I. T. and Kim S. G. (2011). A simple and efficient micrografting method for stably transformed Nicotiana attenuata plants to examine shoot-root signaling. Plant Methods. Vol 7. pp. 34.

Gaion L. A., Braz L. T. and Carvalho R. F. (2018). Grafting in vegetable crops: a great technique for agriculture. International Journal of Vegetable Science. Vol 24. pp. 85-102.

Goldschmidt E. E. (2014) Plant grafting: new mechanisms, evolutionary implications. Frontiers in Plant Science. Vol 5. pp. 1-9.

Grigoriadis I., Nianiou I. and Tsaftaris A. S. (2005). Shoot regeneration and micrografting of micropropagated hybrid tomatoes. Journal of Horticultural Science and Biotechnology. Vol 80 (2). pp. 183-186.

Gulati A., Schryer P. and McHughen A. (2001). Regeneration and micrografting of lentil shoots. In vitro Cellular and Developmental Biology - Plant. Vol 37. pp. 798-802.

Ha N. T. (2009). Effects of rootstock on yield and disease resistance in tomato grows in early spring 2007 in Thai Nguyen. Journal of Science and Technology. Vol 51. pp. 1-4 (in Vietnamese).

Hamaraie M. A. A., Osman M. E. and Mohamed A. A. (2005). Propagation of grapefruit by shoot tip micrografting. Proceedings of the Meetings of the National Crop Husbandry Committee - Sudan $38^{\text {th }}$. pp. 215-219.

Mihaljević I., Dugalić K., Tomaš V., Viljevac M., Pranjić A., Čmelik Z., Puškar B. and Jurković Z. (2013). In vitro sterilization procedures for micropropagation of 'OblaČinska' sour cherry. Journal of Agricultural Sciences. Vol 58. pp. 117-126.

Johkan M., Mitukuri K., Yamasaki S., Mori G. and Oda M. (2009). Causes of defoliation and low survival rate of grafted sweet pepper plants. Scientia Horticulturae. Vol 119. pp. 103-107.

Kendon J. P., Rajaovelona L., Sandford H., Fang R., Bell J. and Sarasan V. (2017). Collecting near mature and immature orchid seeds for ex situ conservation: 'in vitro collecting' as a case study. Botanical Studies.
Vol 58. pp. 34. doi: 10.1186/s40529-017-0187-5.

Khalafalla M. M. and Daffalla H. M. (2008). In vitro micropropagation and micrografting of gum arabic tree (Acacia senegal (L.) Wild). International Journal of Sustainable Crop Production. Vol 3. pp. 19-27.

Khan S. V. P. S., Prakash E. and Rao K. R. (2002). Callus induction and plantlet regeneration in Bixa oreliana L., an annatto-yielding tree. In vitro Cellular \& Development Biology - Plant. Vol 38. pp. 186-190.

Li D., Baldwin I. T. and Gaquerel E. (2016). Beyond the Canon: within-plant and population-level heterogeneity in jasmonate signaling engaged by plant-insect interactions. Plants (Basel). Vol 5 (1). pp. 14. doi: 10.3390/plants5010014.

Majhail H. S. and Singh K. K. (1962). Inarching in mango. II. The optimum period of grafting and age of stock seedling. Punjab Horticultural Journal. Vol 2. pp. 109-113.

Melnyk C. W. (2017). Plant grafting: insights into tissue regeneration. Regeneration. Vol 4. pp. 3-14.

Melnyk C. W. and Meyerowitz E. M. (2015). Plant grafting. Current Biology. Vol 25. pp. R183-R188.

Miles C., Wimer J. and Inglis D. (2015). Grafting eggplant and tomato for verticillium wilt resistance. Acta Horticulturae. Vol 1086. pp. 113-118.

Mneney E. E. and Mantell S. H. (2001). In vitro micrografting of cashew. Plant Cell, Tissue and Organ Culture. Vol 66. pp. 49-58.

Murashige T. and Skoog F. (1962). A revised medium for rapid growth and bio assays with tobacco tissue cultures. Physiologia Plantarum. Vol 15. pp. 473-497.

Naz A. A., Jaskani J. M., Abbas H. and Qasim M. (2007). In vitro studies on micrografting technique in two cultivars of citrus to produce virus free plants. Pakistan Journal of Botany. Vol 39. pp. 1773-1778.

Regnault T., Daviere J. M. and Achard P. (2016). Longdistance transport of endogenous gibberellins in Arabidopsis. Plant Signaling and Behavior. Vol 11: e1110661. doi: 10.1080/15592324.2015.1110661.

Rehman H. and Gill M. I. S. (2015). Micrografting of fruit crops - A review. Journal of Horticulture. Vol 2. pp. 7.

Rzepka-Plevneö D., Kulpa D., Grabiec M., Kowalczys K. and Kurek J. (2006). The effect of growth regulators and culture conditions on the callus induction in tomato Lycopersicon sp. Acta Scientiarum Polonorum, Hortorum Cultus. Vol 5. pp. 23-24.

Sanjaya, Muthan B., Rathore T. S. and Rai V. R. (2006). Factors influencing in vivo and in vitro micrografting of sandalwood (Santalum album L.): an endangered tree species. Journal of Forest Research. Vol 11. pp. 147-151.

Tanuja P., Thippesha D. and Kavyashree N. (2017). Effect of age and curing of scion on cost: benefit ratio of softwood grafting of sapota (Achras zapota L.). International Journal of Current Microbiology and 
Applied Sciences. Vol 6. pp. 2678-2682.

Tsutsui H. and Notaguchi M. (2017). The use of grafting to study systemic signaling in plants. Plant Cell Physiology. Vol 58. pp. 1291-1301.

Turnbull C. G., Booker J. P. and Leyser H. M. (2002). Micrografting techniques for testing long-distance signalling in Arabidopsis. Plant Journal. Vol 32. pp. 255-262.

Vu N. T., Kim Y. S., Kang H. M. and Kim I. S. (2014).
Effect of red leds during healing and acclimatization process on the survival rate and quality of grafted tomato seedlings. Protected Horticulture and Plant Factory. Vol 23. pp. 43-49.

Zhang M., Wang Z., Yuan L., Yin C., Cheng J., Wang L., Huang J. and Zhang H. (2012). Osmopriming improves tomato seed vigor under aging and salinity stress. African Journal of Biotechnology. Vol 11. pp. 6305-6311. 